\title{
IV: SPIES AND JOURNALISTS: Aristocratic and Intelligentsia Publics
}

Bavreli's dream about the general and the writer reminds us that throughout the period of its publication (1866-1885), the newspaper Droeba remains a house divided as an expression of two uneasily coexisting notions of "society" (sazogadoeba). Both conceptions of society are united, perhaps, in dividing enlightened "readers of Droeba" from the illiterate people ( $x a l x i$ ) of Georgia, but otherwise they are quite different. One of them is basically an urban aristocratic model of society, which treats the new culture of circulation of the newspaper as being an extension, or augmentation, of the face-to-face publics of the urban aristocracy centering on the viceroy's court in Tbilisi. This urban aristocratic society found its publicness as much on face-to-face ritual displays of commensality and hospitality between known contemporaries, particularly feasts called supras, as it does on circulation of texts. ${ }^{1}$ The other is "society" in the sense of a emergent intelligentsia public (sazogadoeba derived from the sense of the adjective sazogado as "of general, public interest"), a new culture of circulation in which one's public voice would be sharply divided from one's embodied status attributes or any face-to-face "society," in which a new kind of disembodied voice, of a new kind of person, a nonaristocratic Georgian writer, a complete stranger, a nobody, like Bavreli, was at home.

As I will show in this chapter, the differences between these two understandings of "society," often latent in the capital, Tbilisi, where many important aristocrats were also writers, can be seen more clearly on the periphery in Ottoman Georgia. In Tbilisi, after all, Georgian generals and journalists might mingle together at a face-to-face society function like a supra (ritual feast), but in Ottoman Georgia, the anonymity of the imperial spy and the professional journalist, and the local hospitality their work depends on, are very different. In both these different understandings of society, the category of hospitality plays a crucial role as a kind of infrastructure of circulation alongside, for example, roads. ${ }^{2}$ Hospitality in different forms both directly enacts the "representative publicness" of aristocratic society as a culture of 
circulation and also serves as a seen-but-unnoticed infrastructure to the circulation of strangers in strange lands that also makes liberal print culture possible.

At the same time, the aristocratic model of society, which privileges embodied ritual forms of publicity (often embedded in aristocratic acts of largesse and hospitality like the supra by which the host encompasses the guest (on moral discourse of the supra see Kotthoff 1995, Mars and Altman 1991, on the ways that hospitality creates hierarchy see Meneley 1996, Valeri 2001)) over disembodied, relatively egalitarian, textual ones, received its greatest test on the eve of the reunification with Ottoman Georgia. In 1878, Georgian aristocratic society celebrated the reunification of the long-lost Georgians with a society supra in Tbilisi to which representatives of Ottoman society were invited as guests. At this society supra, which was simultaneously reported in the press, the toasts expressed a notion that the reconciliation of the two Georgias would be as simple as recognition "at a glance" in this ritual context. In the coming months, however, this aristocratic ritual model of publicity and its theory of Georgianness as a largely secular set of signs of shared "nationality" that permitted mutual recognition at a glance would be dashed to smithereens by the shocking fact of nonrecognition displayed by the muxajirat, the massive flight of Ottoman Georgians from the conquered territories. This same shocking event thus contributed both to changing models of publicness and changing models of the nation: aristocratic models of society and publicity (the supra) could no more encompass Ottoman Georgia than secular models of Georgianness articulated in toasts at the supra.

The opposition between the two notions of society displays the contrast between what Habermas calls "representative publicness" (Habermas 1991, 5-14), in which a specific group within the social whole, say, the aristocracy, seems to embody in their very persons the property of publicness and displays it before an audience, as in a ritual feast or in a theater, and a "bourgeois" notion of disembodied publicness mediated entirely by the circulation of texts. It is noteworthy that the newly urbanized Georgian aristocracy found their most typical and distinctive "public" genres in the domain of theater, including both European-style theatrical performances and tableaux vivants; the world of Georgian European-style urban theater was born in domestic interiors of urban aristocratic households with aristocratic actors and 
retained this aristocratic character when the performances moved to public theaters (for example, Grishashvili 1963, 197, [who contrasts this "high" European mode of theater with existing popular urban traditions of "Oriental" street theater and puppet theater], Saqvarelidze 1956, compare Habermas 1991, 14).

Aristocratic urban "society" is thus based on the ability of the aristocracy to embody publicness in their own persons, and it therefore stands to reason that they would privilege and monopolize genres of embodied public performance (feasts, rituals, and theater, which, after are all related forms, see Valeri 2001, 9-10) over disembodied texts favored by the intelligentsia. In effect, Georgian theatrical publics grow out of, and remediate, the representative publicness of the Georgian urban aristocracy and the ritual of the viceroy's court. The two senses of society also reveal elites with very different teleologies and senses of social totality in which they located those teleologies, founded on very different notions of "service," as well, imperial service defining society as an imperial court society or an aristocratic service estate, versus a sense of service "to the people" defining a journalistic public defined on the pages of Droeba. Yet for all these differences, throughout the period in question, these two forms of society participated in each other's forms of publicness: society supras were publicized in the press, and many of the figures of nineteenth-century print culture belonged to society in both senses, writers who were also aristocrats. The categorical opposition between the two forms of society or publicness is complicated by the continuities and proliferation of hybrid forms on the ground.

The defining generational debate about the nature, composition, and social function of "society" of the same period did not take place on the pages of Droeba, rather, it took the form of a poetic exchange conducted largely outside the domain of public print culture, being exchanged as manuscripts and only latterly published, within the Georgian aristocracy. As Ilia Chavchavadze characterized it, the literature of the older generation of aristocracy was a "domestic" (shinauri) literature: "I call it 'domestic' because it was born among intimates [shinaurobashi] and so circulated within a small circle of intimates [shinauroba], because at that time neither journals and newspapers existed, nor was there a custom of printing separate books" (Chavchavadze 1977 [1892], 172). From its form and circulation, Chavchavadze deduces its 
content, which had nothing universal (saqoveltao) to say to a general public; consisting primarily of lyric poetry based on European models, its content was primarily expressive of the individual poet's vagaries of affect rather than any sort of progressive social thought (1977 [1892], 172). According to Chavchavadze, its only progressive quality was formal, the gradual adoption of European forms and the spurning of inherited Persian poetic forms (1977[1892], 175). ${ }^{3}$ Just as pseudonymous writers like Bavreli were the model members of the republic of print, the model for aristocratic courtly society was the poet, the preferred mode of circulation was the manuscript copied and transmitted by hand between known consociates. In fact, it was precisely this contrast, between plebeian journalists and aristocratic poets, that seemed to typify the generational opposition for the older generation of aristocrats. However, this was a debate about journalism to which plebeian journalists were not invited.

The well-known, generation-defining debate between the "fathers" and "sons" of the 1860s-1870s began when Prince Ilia Chavchavadze circulated, in manuscript form, a series of satirical kenning sketches (titled Gamocanebi "Riddles" [Chavchavadze 1977 (1871), 88-91]) satirizing members of the nobility. Prince Grigol Orbeliani, a prominent aristocrat, service noble, general, and poet of the older generation, responded to this provocation with a poem titled "Answer to the Sons" (Pasuxi Shvilta Orbeliani 1959 [1874, 67-72]), thus framing the debate as a debate between different generations of the Georgian aristocracy. This debate happened in the early 1870s, around the same time as Chavchavadze was writing polemical engagements with Orbeliani and others in Letters of a Traveler (1871). In his poem, Orbeliani chastised Chavchavadze in particular and the younger generation of Georgian aristocrats in general for turning away from the deeds that characterized the older generation of nobility, service in the sense of specifically military service as generals in the Russian army, just as they had turned away from the classical language. Angered by the way that Chavchavadze had satirized Georgian nobles who had fought for the fatherland (mamuli) as generals in the mountains of Daghestan, he characterizes the new generation's notion of service to the fatherland with sarcastic dismissal: 
St'ambit mohpinon sc'avla mamulsa!

Aghchndnen mc'erlebi, Zhurnalist'ebi
With the press, they will spread learning in the fatherland! There have appeared writers, journalists.

(Orbeliani 1959 [1874], 72)

Chavchavadze, adopting the same meter as his opponent in his "Answer to the Answer" (Pasuxis Pasuxi, Chavchavadze 1977 [1872], 97-101) not only defended his use of an (ever so slightly) more popular, less classical version of the Georgian language, but more importantly, agreed to this characterization of the distinction between the two generations of nobility in terms of their different notions of service and relations to the state. In Chavchavadze's characterization of the opposition, the older generation was characterized by its position on the table of ranks in the Russian service nobility, chini, the younger by a lack of such a relation to the state. He begins his reply as follows:

\section{Chven uchinoni}

Chven uchinoni

Tkven, chinianta, buzad

ggonivart...
Us who lack rank

Us who lack rank

You, who have rank, think are

flies...

(Chavchavadze 1977 [1872]: 97)

For Orbeliani, turning away from poetry and classical versions of the Georgian language to journalism and the language of the press was in a sense equivalent to turning away from the life of heroic service to the state as a general to the life of a mere journalist. For Orbeliani, this was equivalent to leaving the aristocratic ideals of expression behind entirely; hence the parallelism between moving from general to journalist is also a debate about the proper form and language of poetry.

Since the ranks of journalists include both aristocrats (Chavchavadze) and nonaristocrats (Sergi Mesxi, editor of Droeba for most of the period from 1869 to 1882), what began as a debate within the aristocracy (conducted in an entirely aristocratic form and forum of exchanges of poetry in manuscript form) over the proper form of aristocratic service (and the appropriate form of the Georgian language) became imme- 
diately a debate over aristocratic and emergent intelligentsia notions of publicness. It was, however, a debate in which only aristocrats were welcome to, or able to, participate. Ilia Chavchavadze, as a wayward son within the aristocracy, would never sustain the level of hostility of criticism from Orbeliani that journalists like Mesxi, who were nonaristocratic in origin, would. Indeed, Orbeliani and Chavchavadze, for all their savage sparring, remained lifelong friends in the manner that aristocrats will. Nonaristocrats like Mesxi are neither addressed by these poems nor able to reply, since they do not command the poetic register and most importantly, simply because they are not aristocrats. They are spoken of savagely in the way that one might speak of someone who cannot talk back. Elsewhere, Orbeliani even more savagely attacks the nonaristocratic outsider Mesxi, criticizing the language of Droeba (in a satirical poem entitled "for the ten-year jubilee of Droeba" [Orbeliani 1959 (1876), 75]) as "the language of the bazaar, of an Armenian." Ironically enough, this urban "language of the bazaar" that Orbeliani disdains in his public persona is precisely the language that Orbeliani would adopt in his private cycle of "oriental" urban muxambazi poetry (Ram 2007, Manning 2004, 2009c, Manning and Shatirishvili 2011).

\section{Spies and Journalists in Ottoman Georgia}

This poetic debate encapsulates many of the key oppositions of the period, over the nature of publics and the genres and kinds of language used to address them, but also the specific novel ways that Georgian aristocrats saw themselves in service to the public (generals versus journalists, service to the state versus service to "the people"). Most importantly, it shows the way that what begins as an internal opposition within aristocratic "society" (Orbeliani versus Chavchavadze, "father" versus "son") had by now become an external opposition between aristocratic "society" (Orbeliani) and an emergent nonaristocratic intelligentsia "public" (Mesxi). These emergent differences emerge most clearly a few years later on the ground of the newly conquered territories of Ottoman Georgia. We need only go back to Bavreli's Aesopian dream about the general and the writer to see how very different the terms of engagement between servants of the state (generals) and servants of the people (writers, journalists), the former imagined as a cosmopolitan imperial category consisting indifferently of Russians or 
Georgians, the latter a clearly "local" category imagined as being either Georgian or Mingrelian, were on the ground in recently conquered Ottoman Georgia.

The generational schism between Orbeliani and Chavchavadze, between the general and the writer of Bavreli's dream, is echoed in two travel accounts from Ottoman Georgia during the same period, one by Giorgi Qazbegi (1839-1921), a near relation of the writer Aleksandre Qazbegi and a Georgian officer serving as an imperial spy prior to the 1877-1878 war, the other by S. Bavreli himself, serving as a correspondent to the Georgian press, immediately after the war. While the two authors share more or less the same itinerary and, as Georgians of their period, similar interests in the Georgian ruins that dot the landscape and the Georgianness of the people preserved in customs and language, it is the contrasts between them and the conditions of their travel that illustrate all the generational tensions discussed above, the tensions that are the hidden theme of Bavreli's dream.

The first difference, of course, is that Qazbegi is a spy in the service of the Russian state, writing in Russian, surveying the countryside and mapping the roads of an enemy country in anticipation of a future war; while Bavreli is a correspondent for Droeba, writing in Georgian to a Georgian public, traveling these same roads after the Russian victory. We are reminded that like most colonial print cultures, Georgian print culture is a subaltern print culture, a younger brother of Russian imperial print culture, always finding its object already spoken about by its older brother. While Bavreli is a non-noble writer, Qazbegi is a service noble from a Georgian noble family created ex nihilo by the Russian state. Bavreli's only patron is the editor of Droeba, Qazbegis's entire career is the result of personalistic patronage of the imperial viceroy, like most imperial bureaucrats crossing the Dariel pass, a frequent guest in the Qazbegi house. Bavreli hides his identity from his own public under a pseudonym, but speaks openly of himself and his mission to his hosts in Ottoman Georgia; Qazbegi is a Russian imperial spy, hiding his identity and mission from his hosts in Ottoman Georgia, but publishing his story (in Russsian) under his own name. Bavreli is writing about the disastrous effects of the conquest of Ottoman Georgia, Qazbegi is planning it. Both are anonymous travelers, but the anonymity of the journalist before a public and the anonymity of the spy working on behalf of the state are very different ways of being "nobody-in-particular." 
But the most striking differences between the two are the conditions, and pretexts, upon which they take these voyages, and the way that their respective statuses changes the way they travel and what kind of hospitality they receive from their hosts (which both writers assiduously chronicle). Giorgi Qazbegi was in many ways a typical exemplar of Orbeliani's model of Georgian aristocratic service to the Russian Empire. The entire Qazbegi family, from their noble title to their surname, was a creature of the Russian colonial state, every bit as much as the Georgian military road they presided over. The same is true of the individual career of Giorgi Qazbegi. Given an education at the behest of the Viceroy Vorontsov (a frequent guest at the Qazbegi household, which, after all, was in the Dariel pass, the only practical route between Russia and Georgia), Giorgi quickly rose through the ranks of the imperial army (Xarazi 1995, 7-8). In the early 1870s, the generals of the Russian army determined that, given the difficulty of sending spies into the disputed territories between Russia and the Ottoman Empire, they might avail themselves of local help and decided to send Georgian service nobles who were closely related to the leaders of Ottoman Georgia, using the ties of hospitality and kinship as a cover for a spying and scouting mission. The general they chose was Grigol Gurieli (1812-1891), who was a relative of the Ximshiashvilis, the ruling aristocratic dynasty of Ottoman Georgian provinces Ajaria and Shavsheti. Since Gurieli did not have the requisite geographical training for the mission, they sent Qazbegi, who had specialized training in the requisite areas, ostensibly as a minor aide in Gurieli's camp (Xarazi 1995, 8-9).

Qazbegi's recounting of his travels are remarkably disingenuous, casting his espionage as being disinterested scientific description whose final public is not the Russian state, but European science into which the Russian state's interests are uneasily elided: "Europe knows nothing about many of the places seen by me in this area," Qazbegi says, and when he says "Europe," he means more specifically "European science," which "knows less about some places . . in Turkish Georgia, than Inner Africa" (Qazbegi 1995 [1875], 29). Amazingly, given that he is, in fact, an imperial spy, he represents the apparently completely accurate Ottoman suspicions of the intentions of scientific travelers like himself as being a signal of their own irrationality and backwardness: 
Travel in Asian Turkey is not only dangerous, especially in places along the Russian border, and at the same time for Russians. Our neighbor imagines a threat in everything. For that reason a myriad hindrances lay ahead of the traveler's every step, every question, and especially every attempt to write down or draw something. The interests of science are incomprehensible not only to the people, but to the government of Turkey, as well. For that reason the open and systematic collection of materials to describe the country is for the time being impossible. The only outcome is the write down everything seen and heard from memory, or, in the best circumstances writing down incomplete accounts of impressions. (Qazbegi 1995 [1875], 29)

Their suspicions, in the case of Qazbegi, were of course, completely correct. Sherif Ximshiashvili, one of their hosts, eventually became suspicious about this scribbling aide de camp and sent Qazbegi packing, with profuse apologies, even after such a gross violation of the norms of hospitality by his guests (Xarazi 1995, 9)! The conditions of possibility for Qazbegi's spy work was entirely based his systematic abuse of hospitality, on aristocratic linkages of kinship and obligations of hospitality between Georgian service nobles (Gurieli) and the local Ottoman equivalents in the service of the sultan (the Ximshiashvilis).

Perhaps appropriately, given the bad faith in which he accepts this hospitality, Qazbegi experiences their hospitality as a tedious burden; he dutifully describes the Oriental hospitality upon which his mission depends but finds tiresome drinking coffee a la turca four to five times a day in the company of Begs in Sxalta (Qazbegi 1995 [1875], 39), or ten times a day in qavaxanas the town of Artvin (Qazbegi 1995 [1875], 111). Qazbegi is most comfortable neither in European-style guesthouses of Begs nor Oriental qavaxanas, but rather, in a space in nature's bosom where, for once, they can escape the "hospitality turned into a dogma" (Qazbegi 1995 [1875], 61) that characterizes both the Orient and the Caucasus, and instead of drinking coffee a la turca, instead drink Muscovite tea from a samovar:

At the Duz-Gurji stop our caravan spent an enjoyable 
night. We felt for the first time after Abastumani that we were not guests, our Tula samovar hosted us with Muscovite tea as if we were at home, after which we slept under gigantic beech trees. To memorialize our stay for future travelers we cut several Russian and Georgian characters in these trees. (Qazbegi 1995 [1875], 137)

Qazbegi, in short, is a bit of an ungracious guest; he receives the best hospitality available in the region under false pretexts, and complains about it anyway. By contrast, while Bavreli, as a nonnoble, must sometimes spend the night in the hut of a mountain Kurd or a qavaxana on the banks of the Choroxi, he is much less churlish about the hospitality he is given, on which his travels ultimately depend. Like Qazbegi, Bavreli's main worry is that he will be mistaken for an agent of the Russian Empire, the only difference is that Qazbegi is in fact such an agent, and Bavreli is not:

The contemporary inhabitants too are very hospitable. When I first entered the village, they looked at me as being somehow untrustworthy,- - they thought I was a 'Urusi' and asked each other in Tatar (they thought I couldn't understand):

-What does this Giaor want? He's not a constable [iasauli], is he? He's not demanding soxra, is he?

When they found out, that I was none of those and that I knew the language, too, then with great respect they asked me to stay one or two days. I refused. They brought me a good meal, which consisted of sweets ... 4

Of all the forms of hospitality offered him by his aristocratic hosts, Qazbegi is most thankful for their maintenance of the roads (Qazbegi 1995 [1875], 47). Certainly, all travelers are thankful for this form of generalized hospitality, but Qazbegi, the imperial spy planning a conquest, is particularly so. He is as generous as he is detailed in his discussion of the (as yet unfinished) hard surface Batumi road (a description which fills a number of pages: Qazbegi 1995 [1875], 104-108). A sample: 
From the village of Batsa itself the surface [of the road] is mortar mixed with lime, but for the first four versts [a little more than 4 kilometres] clay predominates. It presents to us all different kinds of colors-from yellow to violet. The road's width is from 2 to $2 \frac{1}{2}$ sazhen [4-5 metres]. . . . Although the existing road is only an embankment for the future paved road, which perhaps in its finished form will present itself to us as one of the best constructions of European roads.

(Qazbegi 1995 [1875], 106)

While all travelers like a good road, Qazbegi seems to truly love roads. This is not really surprising; he has an almost hereditary affinity for roads. His entire family owes their noble status and wealth to that singular road connecting Russia to Georgia, the Georgian military road through the Dariel pass. The Qazbegi family and the Georgian military highway were created at the same time, their destiny intertwined.

The only features of the nonhuman landscape Qazbegi lavishes more pages of description on than Ottoman roads are the ruins of Georgian churches (e.g., Qazbegi 1995[1875], 41-43; 78-81; 87-89; 100-103; 143-147). Roads and ruins form a nonhuman material dyad emblematic of his own disemic perspective from which he surveys these lands as a Russian imperial spy and a Georgian national. The cosmopolitan figure of the road stands for progress, civilization, the future, and commerce (which he both commends in the abstract but also sees as being alien to the Georgian character, Georgians are not traders, and the local Georgians have not betrayed their Georgianness at least in that respect [Qazbegi 1995 (1875), 38]) and planned future conquest; the national figure of the Georgian ruin (always a church) stands instead for his own sense of national specificity, belonging, rootedness, but it is also a sign for the past that these lands once belonged to the Georgian nation and provide an excuse for reconquest to its imperial protector, Orthodox Russia (on the compatibility between imperial cosmopolitanism and notions of national specificity in the context of the period, see Jersild 2002, 60). Both these nonhuman orders stand for different temporal orders (European roads [future], Georgian ruins [past]) opposed to the human order of the Ottoman ethnographic present. 
His explicit comparison of the Batumi road with the absolute standard, European roads, reminds us that for Qazbegi, roads stand to Europe and progress as roadlessness and stasis to Asia. Pages later, as he is wrapping up his description of the Batumi paved road, he pauses to consider its world-historical significance for the region of Livan:

While discussing the Batumi paved road, we must mention that, in our opinion, this road creates a new epoch in the history of Turkish Georgia. From the beginning of the century in Livan the lack of roads for wheeled transport and as well as the character of the landscape itself conditioned the centuries-long stasis of the described territory. As is known, wheels bring with them civilization and trade, while without the wheel there will be neither the one nor the other. Without the Batumi road for trade, the wealth of Livan, Shavsheti and Artvini would become dead capital and the influence of Europe, which has enlightened many corners of Asia, would remain beyond the stone walls encircling Turkish Georgia. We have talked for a long time about the necessity of breaching of these walls and opening the gates of this country for trade. [He goes to describe the benefits for trade that would follow such a 'breaching' of the walls]. It is possible this [Batumi] road will even be turned into a transit highway between Europe and Persia. (Qazbegi 1995 [1875], 107-8)

Even as he praises the European engineering of the Batumi road, he criticizes the shortsightedness of Ottoman rule for not building or maintaining key roads, strangling commerce and leaving Ottoman Georgia (particularly those road regions that are on the marchlands with the Russian Empire) in a stasis characteristic of Asia. The "stone walls" he speaks of here are figurative, but it is striking how quickly he moves from praise for the really existing Ottoman-built road system as a sign of progress and history and its benefits for commerce to comparing Ottoman rule to a set of "stone walls" that prevent commerce, enlightenment, and can only be taken down by (Russian) conquest.

Qazbegi sets up a complex and ambivalent representation of Otto- 
man rule as being on the one hand "European," symbolized by the very concretely material "European" paved Batumi road (and by the guesthouses furnished in European style furnished by local Begs), and on the other hand "Oriental," for which he constructs an opposed purely metaphoric set of "stone walls." But his praise for the impersonal hospitality of good roads reminds us that the hospitality upon which all travel depends takes different forms, ranging from those embedded in personal networks of kinship or friendship (either aristocratic kinship or the fictive kinship institution of the konaghi/kunak relationship, a long-distance relation both of asymmetric patronage in some locality, as well as reciprocal hospitality and friendship found throughout the Caucasus [Bagby 2002, 132-133]), to those expressed materially in architectures or infrastructures of hospitality addressed to indefinite strangers like the qavaxana, the coffeehouse which is also an inn (which is, after all, the model for the putatively specifically modern and specifically European stranger-sociability of the English coffeehouse or Parisian café [Ellis 2008], on coffeehouses as infrastructures, see Elyachar 2010,454), to the completely impersonal hospitality addressed "to whom it may concern" of the roads. ${ }^{5}$

\section{The Cosmology of Pavement: \\ Sociotechnical Infrastructures and Social Imaginaries}

The Batumi road, then, belongs to multiple cosmological orders: (1) opposed to Georgian ruins, as the Ottoman present to the Georgian past; (2) as a "European" road opposed to the metaphoric "stone walls" of Livan, it stands as a symbol of progressive European circulatory civilization to the stasis and obduracy of Asia; (3) the maintenance of the road by the local beg is of a piece with the other forms of hospitality offered by the begs to guests of appropriate status (from European-styled guesthouses to Oriental meals), (4) but at the same time, like associated networks of qavaxanas, it is an infrastructure of hospitality that is addressed to indefinite strangers, irrespective of their status, one which makes possible the travels and correspondence of aristocratic spies and plebeian journalists alike. Commenting on the state of the roads, then, is central, rather than peripheral, to the reflexivity that constitutes the public of a newspaper like Droeba, because it reminds the reader that the ever-thematized, ever-topical deficits of the material infrastructure 
in a country painfully aware of its own backwardness compared to the normative and teleological aspirational model of historical and civilizational progress, Europe.

In contrast, contemporary theoretical discussions of cultures of circulation and publics frequently proceed without any discussion of infrastructures of circulation, leading to an almost entirely dematerialized and deterritorialized notion of publicity. Taylor, for example, divides publics very strongly into an embodied face-to-face, spatialized or "topical" public (the word "public" is often in scare quotes for Taylor [1995] when applied to spatial face-to-face assemblies) and a despatialized, dematerialized, transcendent, nonlocal "metatopical" public (Taylor 1995, 263). Between these two extremes of the absolutely faceto-face and the sublime horizons of metatopical circulation, the middle ground of mediating material architectures and infrastructures, road networks, and city streets, qavaxanas, and cafés, is completely erased. Within such a sociocentric paradigm in which publicness is essentially a property of discourse, and which strongly divides discursive publics into those which consist of face-to-face consociates and those that consist of imagined contemporaries, there is simply no way to conceptualize publicness as a property of material spaces (architectures of stranger sociability of various scales, from cafés to cities [Kaviraj 1997]), nor is there any way to conceptualize the relationship between the deterritorialized stranger of the text and the stranger in the café or on the city streets.

It is true that certain respectable "public spaces" like coffeehouses make cameos in this literature (famously for Habermas [1991, 30-3, 42], but also Taylor [2002, 113]), though almost always in a subsidiary role, providing models for despatialized, dematerialized publics, it is not clear what role they play in the maintenance of publics once they are established other than providing a "satisfying homology" between despatialized and spatialized publics (Laurier and Philo 2007, 263, but see Cody 2009, 2011a for more complex real and imagined interplays between despatialized and spatialized publics, newspapers and teashops). Thus, public places like the coffeehouse belong to the public sphere only because of their resemblance or kinship to the true model of disembodied publicness of the public sphere. Other places we habitually (and apparently mistakenly) call "public," like the city street, are quite the opposite of publicness. For Habermas, the city street where 
strangers can aggregate to form unruly masses, contains all the violent, coercive forms of embodiment that are muted in the coffeehouse and not present at all in the disembodied public sphere, as Montag (2000) has argued (see also Manning 2007b):

[F]or Habermas, the street is an unruly territory, a place of violent conflict consistently descending into the use of force to back up demands, and as such it departs from the hypothesized peaceful spaces of the public sphere wherein the only force is that of the superior argument most thoroughly reasoned out for all present to hear, understand and [logically] accept. 'To speak from the street', Montag $(2000,141)$ glosses, 'is to speak from outside the public sphere'; it is 'in no way an alternative public sphere', for 'it is precisely not a sphere of rational critique or even discussion at all'. The street and the public sphere are therefore fundamentally separate, even opposed, and ideally should be kept apart and devoid of mixing. (Laurier and Philo 2007, 266)

Thus, the spatial or material dimension of publicness can be recognized only to the extent that it provides "satisfying homologies" with, or is a part of the material circulation of, the privileged, dematerialized, discursive model of publicness. The literature on publics thus aggressively rewrites the everyday meaning of the term "public" itself in normative terms, excising from it most of the spatial practices by which publicness is actually enacted (hence, the use of scare quotes around the term in some of Taylor's writings when it is applied to "topical" spaces; see also Kaviraj 1997):

[For Habermas] the public sphere often appear[s] as a highly 'literary' endeavour, but the reader is told little about the routines of bourgeois men moving around the townscape, walking or going by carriage, meeting, sitting down together, gesturing, laughing, sighing, lifting food or drink to their mouths, talking to waiting staff, and so on. The reader might imagine these practices, the conduct of which cannot but be central to the accom- 
plishment of anything resembling a public sphere, but they remain stubbornly absent from Habermas's own text. (Laurier and Philo 2007, 268)

Another reason for this dematerializing neglect of infrastructures is certainly the desire to avoid any form of technological determinism so characteristic of earlier accounts of print culture. Warner's earlier work begins with a strongly social constructionist approach to print culture (1990, chapter 1 ), which, while certainly a valid counterpoint at that time to the received wisdom of technical determinism, nevertheless seems to have the sole effect of continuing this dematerialization of print culture, silencing the voices of nonhuman actors. Warner's elegant argument seeks to elide the crude ontological opposition in technological determinist positions between material technologies and their symbolic, cultural, and political mediations but in the process seems to reduce the obduracy of materiality into the seamless web of cultural intentions. But as Larkin reminds us (2008, 248-50), the material mediation of objects, technologies, and infrastructures always presents itself as an excess (or lack) of sensuous and causal properties bundled in the material object beyond those mobilized in cultural intentions (Keane 2003). Unlike a symmetric account of infrastructures, such as that offered by Larkin and others, social constructivism fails to allow the "natural world or the device in question . . . to have a voice of their own in the explanation, what is generally captured under the notion of 'obduracy"' (Law 1987, 131).

The strangeness of a new media like a newspaper is one of new vistas and new forms of communication between purely social (human) actors it affords, and this is usually taken to be more interesting than the nonhuman strangeness of infrastructure, which is an "embedded strangeness, a second-order one, that of the forgotten, the background, the frozen in place" (Star 1999, 379). Demoted from sufficient condition to a mere presupposition, for writers on publics like Warner or Taylor, infrastructure simply drops to an aside, a footnote, something fundamentally boring (Star 1999) to be skipped over (or absorbed) in pursuit of something fundamentally more interesting.

[T] here are clearly infrastructural conditions to the rise of the public sphere. There had to be printed materials, 
circulating from a plurality of independent sources, for there to be the bases of what could be seen as a common discussion. As is often said, the modern public sphere relied on 'print capitalism' to get going. But, as Warner shows, printing itself, and even print capitalism, didn't provide a sufficient condition. The printed words had to be taken up in the right cultural contexts, where the essential common understandings could arise. (Taylor 1995, 262)

Social constructivism, in this case, appears to be in the service of demoting technological infrastructure to an irrelevant aside, a necessary, but not sufficient, condition; in the process, print culture becomes implausibly deracinated, dematerialized, idealized, the sensuous and material excesses that artifacts have beyond those qualities are foregrounded and rendered meaningful by social construction are ignored, and can be ignored because their material obduracy, their excesses or lacks that can causally destabilize these constructions, have themselves been domesticated (Keane 2003, Larkin 2008, 248-50). For that to happen, the infrastructure has to be in such good working order that it does not become thematized, but rather, like the form of buried cables and pipes of our cities, the infrastructure of circulation falls out of sight. Such is the aspirational goal of the Georgian intelligentsia, but their common understandings of their plight were formed primarily by talking about the abjection of their material predicament, their backwardness relative to places where infrastructure could be presupposed, and hence, talking about these technical, material conditions were essential to generating these "essential common understandings."

Thus, for theorists of Western publics to talk about roads, or infrastructure in general, seems fundamentally boring, to do so for Taylor or Warner is to miss the point of the generative cultural understandings and the new forms of sociability emergent in metatopical spaces. But infrastructure is only really infrastructure if it works well enough to become boring, to be presupposed, unseen and forgotten. As Star puts it more generally:

People commonly envision infrastructure as a system of substrates-railroad lines, pipes and plumbing, electri- 
cal power plants, and wires. It is by definition invisible, part of the background for other kinds of work. It is ready-to-hand. This image holds up well enough for many purposes - turn on the faucet for a drink of water and you use a vast infrastructure of plumbing and water regulation without usually thinking much about it. The image becomes more complicated when one begins to investigate large-scale technical systems in the making, or to examine the situations of those who are not served by a particular infrastructure. For a railroad engineer, the rails are not infrastructure but topic ... One person's infrastructure is another's topic, or difficulty. (Star 1999, 380)

Thus, for Georgian publics to talk about roads and infrastructure is to talk about the common predicament; it is the very essence of the reflexive discourse constitutive of publics. As we have already seen and will see again in chapter 8, travel writing for Georgians is as often as not defined by writing about the infrastructure as it is by writing about the landscape. The infrastructural difficulties of the postal network of Ottoman Georgia are always topical for Bavreli, who, as a traveling correspondent, must first of all find a way to travel. Like all travelers in Georgia, he confronts an infrastructural system of travel which, first and foremost, as Urbneli points out for the Georgian military highway, is in the service of state agents and not especially designed for civilians such as himself, although passenger transport is in fact one of the secondary purposes of the Russian postal network (Bazilevich 1999 [1927], 45-6). When he is not lucky enough to find a traveling Russian bureaucrat to hitch a ride with, he has essentially four options, either a post wagon, an official's wagon, or gain an official travel letter from a district officer and travel from station to station on a regular run. His other option is to rent horses privately, which is the best means of travel, but also the most expensive. Bavreli's problem is that the post network, with regular runs, has not been extended to Ardahan. Having been refused the first two options and there being no room in the wagon of the third, he is delighted to find a couple of horses to rent cheaply. The problem, he later discovers, is that he only had them so cheaply because one of them was completely blind — and the other had sight in only one eye! ${ }^{6}$ 
The ability to travel is only one consideration for a correspondent; correspondence always requires an act of faith in anonymous contemporaries, specifically faith that the letter deposited in the mail will arrive in the editorial office of Droeba in Tbilisi and not in the corner of an Ossetian postal rider's hut, as Bavreli ruefully notes. But these agents of the postal network are not imaginary beings: as Bavreli travels, he frequently has Ossetian riders as his travel companions, and at a couple points, he pauses to describe the picturesque misery of Ossetian postal stations in Ottoman Georgia. ${ }^{7}$ Bavreli also takes great interest in the problems of road building in Ottoman Georgia, where, he complains, the construction of the planned road between Ardahan and Batumi has been held up by a battle between the engineers and the planners. It is already 1880, and Bavreli has been wandering in the locality for more than two years, and still they have not arranged a simple postal service between Artvin and Ardanuji. ${ }^{8}$ He illustrates the human costs of infrastructural failures with two pictures:

A man, who has halfway become an old man from longing to see his wife and child after two years absence [one suspects he is talking about himself], receives a letter, and this is a registered [zakaznoi] letter too, after two months and it has been opened too! In this letter is written, perhaps, his family's secrets. First fifteen strangers have read it and then the addressee gets to read it. That's great!

Another example: A young doctor, who had made a promise to marry a woman, fate has driven into the wilderness. The doctor writes letters and the woman writes letters too; the letters neither reach the one nor the other. After six months a telegram arrives for the doctor, in which is written:

'I waited and waited a long time for you, but I haven't received from you a single letter, nor any words of comfort, and now I belong to another.' ${ }^{\prime 9}$

Georgian print culture could not presuppose a working, and therefore invisible, infrastructure: the obduracy, and consequent thematization, of the infrastructure, then, like that of the landscape, is always part of, 
has a voice in, the resultant imaginary. In this sense, the intelligentsia social imaginary of Georgian print culture bears comparison mutatis mutandis to what Kelty has recently called, with respect to "geeks" in new digital publics of the Internet, a "recursive social imaginary," a social imaginary that is as concerned reflexively with the sociotechnical conditions of possibility of address as address itself: "If, as Warner suggests, publics are constituted solely through the self-referential and self-organizing system of address, then ... the particular sociotechnical constitution of the means of address may also be the proper subject of a public" (Kelty 2005, 200). Kelty's "geek" recursive publics are similar to Georgian intelligentsia publics to that extent, that they focalize the sociotechnical or infrastructural conditions of possibility of address in a way that the publics considered by Warner do not, because they need not. Georgian intelligentsia publics, like Kelty's geek publics, have a social imaginary which includes nonhuman as well as human actors, explicitly foregrounding both technical and social forms of mediation. For Georgian intelligentsia, discussion of the infrastructure that affords or resists their mode of publicness is directly equivalent to diagnosing the more general problems of backwardness and the intelligentsia predicament: what is to be done? Understanding this sense of infrastructural obduracy focalized in "Oriental" places like Ardanuji compared to the "European" apex of civilizational progress, Paris, is indeed an essential part of understanding the sense of backwardness here, and progress there that gave the Georgian intelligentsia their mission. Bavreli's quasi-magical aerostat is, after all, not so much an image adequate to visualize the sublime aspirational aspects of the culture of circulation as to express the picturesque abject ones, specifically the unrealizable fantasy of an exhausted traveler who is sick of walking on bad roads through hill and dale.

\section{Hospitality and Representative Publicity: A Feast in Tbilisi}

If before the conquest, the noble Qazbegi was a guest among the nobility of Ottoman Georgia, after the conquest, Tbilisian nobility could finally repay that debt of hospitality. The Ottoman Georgian nobles would now be brought to Tbilisi as guests, and Georgians would learn about those newly conquered peoples by inviting them, in turn, to a specifically Georgian style of feast called a supra. Like the smaller meals 
enjoyed by Qazbegi and Bavreli, these larger ritual events carried with them their own specific kinds of food and drink (in the case of the supra, somewhat problematically for the Ottoman Georgian guests, drinking of wine or champagne), and along with them their own epistemic presuppositions and imagined performative efficacies.

The Georgian ritual of the supra (feast) was also the event where the Georgian aristocracy most clearly represented their initial theory of how the reconciliation of the divided halves of Georgia would happen. At the beginning, the "problem" of reuniting the estranged Ottoman Georgians seemed like it could be solved in a single, simple ritual, at the level of aristocratic sazogadoeba, "society," an event that would, in turn, be duly reported before the public of Droeba. After all, what better way to express the integration of these estranged "brothers" than a traditional ritual, a Georgian supra, a traditional Georgian feast involving complex rituals of toasting and drinking wine, itself expressive of commensality and solidarity? ". . . In order that, if nothing else, together, to affirm to them [the Ottoman Georgians] from the beginning at a public/society [sazogado] supra, by brotherly breaking of bread, their own sympathy and love." 10

This ritual event was held in Tbilisi in November 1878, attended by members of Georgian society, both gentry and literary, to which were invited a deputation of some sixteen representatives of Ottoman Georgian "society" (various Begs as well as religious representatives of the millets of Ottoman Georgia, it appears). ${ }^{11}$ Sergi Mesxi, the editor of Droeba, followed the visit of this deputation in his "daily" (dghiuri) column from mid-November 1978 forward with eager anticipation: "This is the first coming into the old capital Tbilisi of our quondam brothers (modzmeebi) and of representatives of people distanced from us by the passing of time."12

Part of the value of bringing these "brothers" and "representatives of the people" together physically with their coeval members of Georgian imperial society was an epistemic one. The face-to-face relationship of ritual conviviality between guests and hosts that would allow them to confirm, at a glance, to each other that these were still Georgians, despite this distance in religion, state and time, nothing "real" had really changed about them, neither appearance, language, custom, nor anything else: 
It is more than two hundred years that they have been separated from us; they have changed their religion, they have [been] subjected to another foreign state, different laws and rules. But one look is sufficient, for a man to discern in them even now the old, real Georgian. The same appearance, the same language, customs and everything else. ${ }^{13}$

But this rhetoric of "recognition at a glance" was largely an a priori one, one that had become almost a dogma by the time of this feast. We have already seen how in 1874 a writer to Droeba imagined such a recognition happening at a glance between these erstwhile brothers in a Parisian café. Three years before this feast, the same editor, Sergi Mesxi, had already stated the problem in these same terms, down to reports of "secret Christianity" (an important dogma about Ottoman Georgians was that they were still practicing Christianity secretly among the ruins of old churches), before the Ottoman-Russian War (1877-1878) in an appeal he issued for more information about Ottoman Georgia in the wake of the publication, in Russian, of Qazbegi's account of Ottoman Georgia in 1875:

Centuries have passed since the Ottoman has seized these lands, during which time the Ottoman has been trying to make local Georgians become Tatars. But, look at the endurance of the Georgian tribe,-aside from religion, they haven't changed anything at all; and even this they were forced to change only by coercion and different Ottoman tricks. Their mother tongue, the character of the people, their customs, even their superstitions and everyday life are traditional, Georgian ... In a word, the entire people of Ottoman Georgian even now have the character of the Georgian people, they have the soul of the Georgian people. They have the appearance of a real Georgian, the customs and life of Georgia; the people, although it is a long time that they have become Muslims, but even now they apparently go about in the ruins of local Georgian churches and bring sacrifices as an expression of belief. ${ }^{14}$ 
Apparently, then, the common Georgianness of the Ottoman Georgians was so well-established that there would be little to do in this ritual event other than do the sort of work that is normal at a Georgian supra, namely, to recognize this brotherhood by saying toasts to glasses of wine, or in this case at a more official "European"-style supra, champagne.

The difference between this aristocratic supra and others of its kind was that this ritual was being reported to a larger audience of the Georgian reading public on the pages of Droeba. This was a sazogado supra, which we can translate either as "society supra" (in the sense of "aristocratic society") or "public supra." It was a moment in which two very different kinds of publicity were commingled. First, there was what Habermas calls "representative publicness," the way that a distinguished part of the social whole comes to represent the social whole itself in a quasi-ritual or theatrical manner, in this case the courtly "society" of Georgian aristocracy, themselves embodied or represented publicness before the other estates (Habermas 1991). This notion of publicness embodied in representative estates, "society," allows publicness to be literally incarnated in the persons of the participants of a single ritual, a supra (see also Valeri 2001 on the publics of aristocratic feasting). The second notion of publicness is not this quasi-ritual sense of representiveness, but a new kind of representation in the press, the second sense of "society" in this period, that is, society as a modern print public, not a face-to-face theatrical public as in ritual, but an imagined relationship between contemporaries reading a newspaper story about a feast. It would appear, initially, that these two forms of publicity, the aristocratic and the intelligentsia notions of publicness, were articulated as "society feast" to "report about a feast to reading society." However, if this feast did not manage to create lasting reconciliations between Russian and Ottoman Georgian aristocratic societies, it was the beginning of signs of a reconciliation between the society of Georgian aristocrats and the society of Georgian intelligentsia writers.

Since this was to be a quasi-representative reconciliation of the "societies" of the two halves of Georgia, the list of those invited would be significant. The guest list includes the most distinguished nobles of Ottoman Georgia, along with representatives of various millets, thus employing a sort of Ottoman notion of representativeness. But Mesxi 
is clearly more interested in delineating the representative publicness of the hosts. The hosts, representatives of Georgian urban sazogadoeba, therefore almost all of whom were nobles, were divided into (1) representatives of nobility proper, the unmarked case, (2) representatives of service nobility, specifically generals, and (3) representatives of literature (most of whom were also nobles): "Everyone, who in this our capital city is distinguished or prominent by their own intellect, genealogy and rank." ${ }^{5}$ Sergi Mesxi, (the nonnoble editor of Droeba, invited to write about, but not speak at, this supra) does not give an exhaustive list of names, but first lists those higher nobility who need no further qualification, beginning with Grigol Orbeliani, followed by generals, and lastly, "the representatives of Georgian literature were nearly all there, with the exception of Prince Ilia Chavchavadze, who was not in the city at the time." While membership in society as depicted in this ritual moment is shown to be defined at the intersection of several overlapping definitions (rank, genealogy, talent), this hybrid whole remains dominated by hereditary Georgian nobility, who are listed first, followed by the service nobles and lastly the writers. Moreover, even the writers are mostly nobles. Similarly, their opposed numbers among the Ottomans list nobles proper first, followed by named representatives of different Ottoman millets. This overlapping definition of society as a whole is carried over into many of the individual members, Grigol Orbeliani is all three, and Akaki Tsereteli is a writer and a noble.

The kind of publicness, then, is representative publicness in Habermas's sense, "society" is incarnated by the presence of representatives of its most distinguished members of each kind. The order of introduction in the newspaper (which introduces the pedigreed nobles first, the writers last) as well as the degree of participation in the ritual (who performs the key ritual role of speaking a toast, versus who is merely an audience or correspondent for the press), underline the way in which this "society" remains aristocratic in focus. All those who speak at the supra are noble, whether or not they are representatives, for example, of nobility proper or literature. Many of the literary representatives do not have noble rank, but Akaki Tsereteli, as one who is both a representative of literature and has rank, is the representative from that group who actually speaks. Within the context of ritual representative publicity, the new form of publicness represented by the writer is only represented by riding on the aristocratic coattails of aristocratic rank. 
This being a Georgian supra (feast), the speeches given (all but one reproduced in full in the pages of Droeba) took the form of supra toasts. At a contemporary supra ritual, not only is the content of the toast significant, but also the order in which toasts are given. The toasts at a supra are a "social network made manifest" in Mars and Altman's felicitous phrase (1991), a ritual mapping of the social universe of those gathered and a recognition of their social ties and mutual obligations. At this feast, too, the toasts produce a diagram of a social universe, here a simplified diagram of the Russian Empire itself, and the place of Georgia nestled within its bosom, which is the space in which the guests and the hosts both find themselves.

\section{Speaker}

1. Grigol Orbeliani

2. Husein-Beg Bezhan-Oghli (Guest)

3. Aleksandre Zubalashvili

4. Dimitri Qipiani (Host)

\section{Akaki Tsereteli}

\section{Theme of Toast}

to the tsar

to the viceroy (Host)

to the people of Russia

to our long-lost brothers

(Guest)

to the ancestors

Beginning with the tsar indicates that the feast is a "public" one. Toasting first the tsar, then the viceroy, establishes a motion from the center of empire to the center of the periphery, Tbilisi, the court of the tsar to the court of the viceroy. Since the empire is a gift not merely from the tsar, next there are thanks given by the Georgians to the "people of Russia," the focal population of the empire (see Grant 2009). The first three toasts, then, establish an "imperial" framework and map out an ontology of imperial representative publicness, an imaginative geography in which the hosts and the guests, Georgians in general, both are now contained after the Russian victory of 1878 . The next two toasts, firmly contained within this imaginative geography of empire, first recognize the common Georgianness of the hosts and guests, and lastly the common cause of their commonalities, the ancestors. The overall order of the toasting then acts as a diagram of an imperial imaginary of Georgian nationality, in which the Georgian nation is firmly and happily ensconced within a broader Russian Empire (just as each individual face-to-face or print public within the empire is established ultimately with reference to the representative publicness 
of the tsar) in which "Georgian nativism was easily compatible with empire” (Jersild 2002, 151):

The 'national question,' however, remained on the distant horizon. Educated society in the borderlands throughout the nineteenth century was thinking through the problem of empire, and the question of cultural 'originality' was compatible with-indeed, fostered by-imperial rule. (Jersild 2002, 152)

If the order of the toasting created a way in which the theme of reuniting Georgia was placed within an imperial bedrock, then the list of speakers, too, produced its own arguments about reconciliation at the level of "society." Each toast was given by representatives of different groups to be constitutive of Georgian aristocratic "society." The two ranking nobles of each deputation were paired off for the first two toasts: Grigol Orbeliani, speaking first both as the highest ranking bearer of rank, also as the most distinguished holder of hereditary noble rank; Husein-Beg Bezhan-Oghli, speaking as the ranking representative of the coordinate Ottoman Georgian "society." Next, two more prominent nobles, Aleksandre Zubalov (Zubalashvili) and so on (a general, presumably speaking for the service nobility) and Dmitri Qipiani, who was speaking primarily as host but also was known at the time as the key representative of the Georgian hereditary landed nobility (see Suny 1988, 97-101), and finally Akaki Tsereteli, though a noble, speaking as a representative of the writers (mcerloba). The aristocracy is its various levels is constituted into a unitary speaking subject (consisting of rank, nobility and talent, although all are nobility), and also seeks to traverse the divide between "Russian" and "Ottoman" Georgian "society."

In content, too, each toast in some sense also stands as a kind of characterization of the sorts of presuppositions that animated later investigators of Ottoman Georgia, but also the way in which Georgian society performatively attempted to integrate their opposite members at the level of educated society. The first toast, to the tsar, for example, by the representative of the older generation, Orbeliani, presents their present happiness as an effect of a distal cause, the tsar. The typical sentimental history of Georgia's past suffering is given an imperial salvation: 
Gentlemen! What does our meeting here today betoken? Why are we happy? What are we toasting? This meeting represents the happy sight, when the children of one mother, separated by black fate, lost to one another for a long time,- - suddenly, unexpectedly meet, recognize one another, and embrace other another with heartfelt love. We too were also such children of Georgia, lost to one another over a period of centuries; we suffered much from enemies, we went through many ravagings, but still we did not forget our separated brothers. We kept our eyes, our hearts on you, gentlemen, and we wished for the day when the sun of unification would rise on us! (In the audience [sazogadoeba] is heard lively applause). And lo, God also heard us, and today among us we see our separated brothers and happily we thank God and we entreat him that this our unification be indestructible forever! . . . And from today forward in both happiness and sadness we must be together, like the sons of one mother, Georgia.

But, gentlemen, who is other than God, the cause of our being so blessed? The all-merciful great Emperor, the restorer and protector of ancient Iveria [Georgia]! And the blessing of God be spread to his glorious crowned head many and many times, joyfully of his great empire. Gentlemen! God bless our great Emperor . . . Hurrah? (After these words a long Hurrah went on uninterrupted for some time in the audience [sazogadoeba]). ${ }^{16}$

After a toast to the viceroy by the Ottoman guest, whose text we do not know, nor do we know what he drank, the next toast by Lord A. Zubalov (Zubalashvili) had a similar structure, again expressing happiness that the "gulf" between the two groups of Georgians, "Russian and Ottoman Georgia," had been eliminated, "now, like it or not, we are our own," a larger unity once again expressed in the microcosm by the fact "we are gathered together at a supra and we toast the destruction of the divide between us, our brotherly gathering in the old way, in our way."'17 Again, this happy occasion in the present locality was at- 
tributed to a distant imperial cause, the Russian people.

The most interesting toast, the crowning and final toast of the evening, was that of the representative of literature, Akaki Tsereteli. The preceding toasts had on the one hand, expressed joy at the return of "our lost brothers" "children of the same mother, Georgia" and so on, but they had attributed and toasted in each case an effective cause which was located outside of Georgia, the empire, first the tsar, then the viceroy, then the Russian people, then a toast, from the host of the supra, Qipiani, to the guests. The crowning and final toast of the supra, the only one addressed to Georgians, Tsereteli's was also the longest. This was a toast to the ancestors, who are represented in rather more nationalist terms as being ultimate cause of the happiness felt, Georgianness being an effect of their accumulated work, the will (anderdzi, "will" in the sense of "last will and testament") of the ancestors. Noting that this supra, unlike any other, had a unique property of unblemished happiness that all felt, Tsereteli begins by asking what explains this quality of unrelieved happiness:

And to what must we attribute this [sc. quality of unblemished happiness]? Although each of us also feels it well, but I must nevertheless say, that its cause is the renewal of our unity and brotherly connection with our brothers who have been estranged from us by the passing of time, whose representatives are seated here. Yes, gentlemen, today we can go to the graves of our ancestors and cry out to them, that we have not yet broken their last will and testament! And what, gentlemen, was that last will and testament?

The last will (including both elements of will and items left to posterity) of the ancestor resides in their accumulated works, language and nationality, which they both bequeath to their descendants and entrust to them:

The first, that is, language, they have so richly adorned and have given to its such a taste also, that not yet have we been able to forget it and not only us, but those brothers of ours as well, who in the course of several 
centuries have been separated from us, even they have retained the mother tongue for sweetly speaking.

The second of these, eroba, nationality, is much more vaguely explained. It again is the product of the work and sacrifice of the ancestors, representing a communal debt of the present to the past. Like language, eroba is conceptualized as a set of signs. These signs have been imprinted by the ancestors on the Georgian both externally and internally, and the content of these signs are simply that they visibly indicate belonging to a nation (eri).

The second, that is, nationality (eroba), they have so richly worked out and have in such a way imprinted it on the Georgian as a property as both external and internal signs of belonging to a nation (eris), that even today a Georgian at a single glance can be recognized. Our brothers also have retained exactly such signs; to prove this let us no longer go far, it is sufficient, that right here, at this supra, that we look back and forth at each other. ${ }^{18}$

Eroba, nationality, then, is a set of signs that indicate membership in the eri, which in turn is constituted by the set of such sign-bearing Georgians. This nationalist toast (not necessarily incompatible with the explicitly imperialist ones that preceded it) provides the epistemic framework of Georgianness necessary to explain how reconciliation between the two Georgias could happen here and now at a supra: this set of signs includes visible external signs of belonging, so that a Georgian can be known even today, "at a glance," here, at this supra, without need to send anyone anywhere to prove it.

Such was the a priori discourse of Georgianness on the eve of the repatriation of Ottoman Georgia, before anyone had actually bothered to go to Ottoman Georgia and see if any of this was actually true. Partially, this was because it would be unnecessary, as Akaki Tsereteli maintained, they could already see that in the context of the supra itself. 
The Crisis of the Muxajirat: The Shock of Nonrecognition In retrospect, four years later, it became clear that the society discourse of "recognition at a glance" was among other things an epistemological failure, as one "Voice from Mohammedan Georgia" explained in 1882:

[At the end of the war] both writers as well as more generally our entire enlightened society met the union of this region with great enthusiasm. At that time, wherever you would look, everyone was talking about it; 'We have found our long lost brothers; they are damaged by the war, let us give them aid, let us raise schools, let us help them in intellectual progress and in other matters of prosperity.' Many such things were said then among us and yet not one person asked this-in what condition did we find 'our brothers'? . .

It is true, many things were being written from this region, many things were said about local administration and its actions, but the people themselves, their intellectual and moral aspects, their specific characteristics, their soul, character and customs and beliefs either no one at all has touched upon, or if someone did, they did so in passing and this too they so represented to the reader, as it really is not. . . I also said this into order to demonstrate this idea, that our society does not know these people at all and when it puts its hand to write about them, error follows upon error. . . .

[S]ociety ... has not represented these people [sc. Ottoman Georgians], as they really are, it has a view of them that is completely contrary to the truth; it looks at them with the same eyes that it looks at other Georgian tribes, but unfortunately historical causes and development of time has so disfigured these people in mind and morals, that only their language and external appearance have remained Georgian,- - all the rest, which constitutes the specific characteristics of Georgians and by which they are differentiated from other neighboring peoples has been smashed to smithereens and extinguished. ${ }^{19}$ 
The epistemological discourse of the supra, cast in the sentimental form of toasts which present a priori truths about which no debate is possible, represented the project of reuniting the two Georgias as a simple matter of mutual recognition which could be accomplished "at a glance" at the level of aristocratic society. But, as was already becoming clear on the same pages of Droeba from correspondents traveling in Ottoman Georgia, the project of reuniting the two Georgias was destined to fail somewhat catastrophically at the popular level. The problem was that far from recognizing their Georgian brothers at a glance, instead the Ottoman Georgians fled en masse. As Pelkmans notes, the flight of the Ottoman Georgians radically disconfirmed the superficial thesis of "recognition at a glance" proposed by Grigol Orbeliani at the supra, and in a private letter of 1879 , he (like most other Georgian writers) wrote with shock "[The Ottoman Georgians] run away from us, as if they are running from the plague! Is it possible that the single explanation for this is fanaticism?" (Cited in Pelkmans 2006, 98.) Faced with such a shocking disconfirmation of their views, Georgian writers frequently cited Ottoman "fanaticism" stirred up by Ottoman mollahs and spies to explain the failure of recognition and reunification between European and Oriental Georgia in Orientalist terms, but the shock also pointed up failures in Georgian society, including the ritually mediated model of representative publicity on which it was based. Each and every presupposition of the supra in Tbilisi in 1878 received a categorical disconfirmation in the unfolding events of the subsequent year: the specifically aristocratic model of society based on ritual and representative forms of publicity, the model of reconciliation by "recognition at a glance" in the ritual context of the supra, and lastly, the widely shared quasisecular model of a common Georgianness based on signs of nationality and language, which served as a semiotic ground for such recognition at a glance that would allow happy reconciliation to happen at the level of society in the context of a single ritual.

Years later, in 1893, it was clear that the family of Georgians remained, and would remain divided, and that, moreover, the work of reuniting the two halves of Georgia could not have been accomplished at the level of sazogadoeba, "society" (rather than among the "people"), by a simple act of recognition at a single feast in Tbilisi, even if it was a very big one. Much more work by Georgian society would have been 
required, involving a whole different model of "society," involving not feasts in Tbilisi but an active "going to the people," and this work was not done. In this year, Il. Alxanishvili concluded a multipart description of a portion of Ottoman Georgia (the first one published in years) with the following pessimistic assessment that placed the blame not on the fanaticism of the Ottoman Georgians, but the indifference of Georgian society:

So that I no longer annoy the reader with talk, I will end my notes of a traveler and, though with such a description in passing it is hard to draw for the reader a complete picture of local nature and customs, but I yet have one thing to ask. What moral dependence do the Georgians left behind on local ruins have on the remainder of the Georgians? None. What has our leading society done to take care that they have moral influence and become closer on these newly found brothers (relations)? Nothing. . . A new period has begun. It is now 65 years, that we have united the Georgians of these two districts, thanks to the sword of Russia [these regions were conquered earlier in the Russo-Ottoman war of 1828-9], first to the gubernia of Kutaisi and now that of Tbilisi, then what have we done in these 65 years? Have we drawn local Georgians in some way (to ourselves)? Not at all. ${ }^{20}$

Both in 1878 and in 1893, the active agent is assumed to be "society," but the nature and sphere of activity of that society has changed considerably. In 1878, the attempt to suture the two kinds of Georgians into one nation is approached as a simple matter of convening their two representative aristocratic "societies" together in a traditional act of commensality, a supra. Aristocratic "society," Russian Georgian and Ottoman Georgian, appear to be transparent representatives of their respective "people."

It is interesting to note that while Habermas (1991, 5-15) posits very little in the way of a bridge between aristocratic and bourgeois senses of publicness (the former embodied as a status attribute, the latter created by the disembodied circulation of texts), treating the 
transition between them as an unmediated historical chasm (Kaviraj 1997, 95 note 12), in the Georgian case, we can see clearly intelligentsia notions of print publicness propagating through the social networks of the aristocracy, little by little converting representative publicness into print publicness (which accords well with the Georgian intelligentsia narrative that gives the intelligentsia aristocratic origins, cf., the commonplace definition of the intelligentsia as an "aristocracy of the soul"). As in Russian Georgia, so in Ottoman Georgia, the development of popular literacy and print publics was felt to depend on the exemplary representative publicness of aristocratic society. ${ }^{21}$ Just as the incorporation of the people of Ottoman Georgia into Russian Georgia would happen through aristocratic representatives at a feast, so the spread of print publics, the propagation of literacy among the people of Ottoman Georgia was to happen through the incorporation of the begs of Ottoman Georgia into Russian Georgian print culture, and propagation of literacy from "society" to the "people" as in Russian Georgia. To this end, the editor of Droeba, Sergi Mesxi, sent seven exemplars of the newspaper Droeba, along with a larger number of small books, to the begs [local nobles] of Ottoman Georgia, the newspapers to be read by the begs and the books to be "circulated among the people." One might easily compare the number of newspapers sent to Ottoman Georgia in 1878 with the number of Ottoman guests brought to Tbilisi for the feast the same year, very likely the recipients and the guests were the same or related people.

Within this aristocratic model of the propagation of literacy, however, is also nestled the emerging categories of a new discourse of publicness, of the duties of writers to the people. Of course, Mesxi admits, seven copies of a newspaper and books whose numbers apparently were no more than a hundred is nothing much. What is important, according to Mesxi, is the desire they show, a "desire to read Georgian and get to know [gacnoba] our life [qopa-cxovreba]": "Today the begs have this desire, tomorrow it can be aroused among the people." ${ }^{22}$ Here aristocratic "recognition (gacnoba) at a glance" (representative, embodied, publicness) is replaced with an intelligentsia conceptualization of the purpose of writing as "getting to know" (gacnoba) the "life" (qopa-cxovreba) of the people. In a sense, then, the tasks presented by Ottoman Georgia were much of a piece, even a model test case, for the general tasks of the Georgian writer with respect to the Georgian people, that is, the 
creation of a popular literature, popular (saxalxo) both in the sense of "folklore," collection of oral folk texts, and also "for the people," the propagation of literacy, all for the purpose of gacnoba (getting to know) each other:

As far as the propagation of popular (saxalxo) literature,- this, of course, is dependent on time. People need to appear among us, who will collect in Ajaria, Kobuleti, Shavsheti, and other re-united regions their compositions of folk (saxalxo) poetry, their fairy tales (zghap'rebi), legends, historical and other traditions, folk poems (saxalxo leksebi) and so on and this will help them both as a means for the propagation of literacy and help us get to know them, too. ${ }^{23}$

By 1893, the nature of society and its duties to the people have indeed been expanded along these lines, and from this perspective, Alxanishvili's assessment is that society in this new sense has failed its new people.

What is interesting about Alxanishvili's account is his treatment of the failure of reconciliation as a failure of society to go to the people, to create moral linkages with them. At the same time, then, the reconciliation of the estranged halves of Georgia can be read as a failure to build an infrastructure of hospitality, a failure of circulation, whether of mutual hospitality or other forms of exchange. The rather meager hospitality offered by Georgian society to their new Ottoman brothers, essentially, amounted to that one single feast in Tbilisi in 1878. As Alxanishvili notes, stresses, nothing comparable happened at the level of the people, and after decades such meager ritual hospitality could not compete with the massive existing networks of horizontal ties of hospitality (konaghi/kunak relationships) maintained by the Ottoman Georgians who remained within the boundaries of Russia to their friends and hosts in Ottoman lands. In place of a single ritual act of commensality, here were many comings and goings, presumably solidified by equivalent acts of commensality, into the relation of the konaghi/kunak, commerce, in short, a whole popular culture of circulation of persons that drew the Ottoman Georgians who remained closer to the Ottomans than to their Georgian "kin": 
Imagine, that even now the Javaxetian Georgian still has turned his face more toward the Ottoman, than to us. They arrange comings and goings, friendship, commerce trade and every moral dependence more to Ottomans and especially again to them. It is hard to find that [Javaxetian] Georgian, who has even gone to Chobis Xeoba and begun with Kartlian Georgians some sort of relationship, friendship, or commerce. The same Georgians have Ottoman konaghis (hosts, protectors) almost as far as Arzrum and arrange among each other friendship and trade. ${ }^{24}$

However, the single greatest shock for Georgians was the shock of non-recognition, as the Ottoman Georgians began to leave in droves for the Ottoman Empire. Variations on the term muxajirat (as Georgian and Russian sources would call it [Georgian muxajiroba, Russian muxajirstvo]) are used for all the mass migrations of Muslim populations from the Caucasus (Circassia, Abxazia, Ottoman Georgia). The term appears to be based on the Arabic form muhajirat ("emigrants"), a term which specifically locates the migration within a Muslim narrative of hijrah from non-Muslim to Muslim lands, modeled on the original hijrah from Mecca to Medina. More problematically, the term implies that these were voluntary migrations, which is hotly debated at both the popular and academic levels. The Ottoman Georgian muxajirat was a large mass population movement (of perhaps over two hundred thousand souls) even in a period known for many deportations and emigrations of extremely large Muslim populations from Russian rule (Jersild 2002). For comparison, the earlier emigrations following the end of the Circassian wars from 1864 onward, which effectively depopulated the coastal regions of Circassia, involved upward of two hundred thousand in the first year, and a total of perhaps four hundred thousand Circassians and two hundred thousand Ajarians and Abxazians. ${ }^{25}$ The happiness of the feast quickly was confronted with the sadness that there would, in effect, be no homecoming and no reconciliation. This shock and disillusionment was largely not affected by the decision of large numbers of Ottoman Georgians to return between 1881 and 1882 (Pelkmans 2006, 99). 
Again and again, Georgian intelligentsia run after the fleeing peasants of Ottoman Georgia to ask them why they are fleeing, only to meet a stolid reticence based on a lack of mutual recognition as Georgians (see also the reported conversations and discussion in Pelkmans 2006, 98-100):

I was happy, thinking "Now I will see and get to know our newly repatriated Georgians!" But soon a certain event wiped away these signs of happiness from my heart. The event-regarding the emigration of the Ajarians. The pitiable people were lined up and with loaded horses, they were hastening off somewhere or another.

- Hello! I told them, but with such disgust, with downturned faces they glanced at me, that a man would have said, that they are angry at me for something.

- Where have you gone, brother! Why do you not say anything to me, I am a Gurji [Georgian in Ottoman dialect]...

- How were we to know, that you are a Gurji? The bad Armenians have learnt Gurjian (Gurjuli), and tell us that 'We are Gurji'! . . .

- But they did not give me an answer to my question. My conversationalist however whispered: Hurry, let's go, to Trapizon a long road awaits us. The moment I heard "Trapizon" I asked:

-What do you want in Trapizon?

-Well what are we to do? We can't stomach Russians [Urusebi]. We have been told that that they will treat us badly, show our women roubles and invite them out to do bad things. We can't tolerate that. ${ }^{26}$

The lack of mutual recognition, of course, emerges from the lack of a shared semiotic ground for such recognition based on a secular model of shared language and nationality. What Georgians discovered in the shock of each event of nonrecognition was something that had already been long reported by travelers before this point. Tsereteli's model of Georgianness, which afforded "recognition at a glance" at the supra in 1878 , was an essentially secular one, which treated nationality as a se- 
ries of outward and inward signs, therefore particularly foregrounding language as a basis of recognition, and passed over the elephant in the room, religious difference, in silence. This model however obviously did not persuade Ottoman Georgians (a fact that was usually explained by their "fanaticism" partially inherent, partially stirred up by Ottoman agents), and importantly, it also did not actually correspond to the discourse of other actors, notably these same Georgians themselves, when they discussed Ottoman Georgians.

The "fanaticism" of Ottoman Georgians, evidenced by their obsessive referral of identity to religious difference (according to impatient Georgians) and refusal to recognize any secular basis for commonality with those they called Gurjis, such as language, was already a matter of record long before 1878 (Pelkmans 2006, 99-100). Indeed, it is an index of wishful thinking and selective reading of earlier accounts that Georgians managed to be surprised at all by the catastrophic disconfirmation of their discourse of the nation. Bakradze, in an oft-cited account, had already noted in 1873 that "the word 'Georgian' (kartveli) is unknown to the Ajarians and they call themselves only 'Ajarians,' but they call their language 'Gurji' language." This lack of recognition that Gurji was not only a language but a secular basis for mutual recognition of being "one people" (xalxi), is blamed on the obfuscating influence of Islam:

it is impossible not to take notice that the consciousness of the Ajarians about their national origin is extremely confused by the influence of Islam: their perspective on this question, like so many others, flows from the viewpoint of religion, and if you try to persuade some of them that religion is one thing and national origin another, and that the unity of our language is the best proof, that both we and the Ajarians are a single people. For their own part, they were telling me 'at some point our ancestors were Gurjis, but after Islam arrived among us. . . Even though we speak Gurjian.' (Bakradze 1987 [1878], 45-6)

The official rhetoric of liberal intelligentsia discourse opposed religious identity to linguistic or "national" identity and was explicitly op- 
posed to Orthodox Christian proselytization (see Moshtashari 2001 for the ambivalent position of the Russian Orthodox authorities about the prospect of converting "ex-Christian" Muslim populations in various parts of the Caucasus). ${ }^{27}$ However, Christian Georgian discourse was as ambivalent about Ottoman Georgians, as Ottoman Georgians were about Gurjis. First of all, despite the apparent secularism of discourse which sought to ignore differences of religion, this apparent secularism was systematically undermined in several ways.

First of all, at the ritual of 1878 itself, Georgian Christians treated certain aspects of their day-to-day ritual practices, like drinking wine at a supra to purely secular toasts, as being thoroughly secular ritual enactments of Georgian identity, which they accordingly expected their Muslim guests to engage in as Georgians. We do not know what the representative of the Ottomans said or drank at the supra (I have heard rumors he drank water, for example), but the fact that the very form (not to mention the substance) of the ritual of reconciliation would be predicated on such a fundamental misrecognition is symptomatic of the whole problem (that this "alcohol test" of loyalty is a continuing form of misrecognition, one of many leading to explicit or implicit exclusion of Ajarian Muslims from Georgian national identity is discussed at length by Pelkmans 2006, 127-9).

But just as Christian Georgians underestimated the religious presuppositions of their own secularism, they tended to impute secret Christian identities to the Ottomans. At the beginning of a long series of articles on "Ottoman Georgia" in the newly launched literary gazette Iveria 1877, even a conservative writer like (editor) Ilia Chavchavadze (mostly remembered for formulating Georgian nationality as being defined by shared "land, language and religion"), apparently converted to a secular nationalist position emphasizing "unity of history" over other factors (including religion and language) in the formation of national identity (see Pelkmans 2006, 99). However, throughout this same series of articles, Ottoman Georgians are continuously represented as "secret Christians," that is, practicing Christianity in secret among the ruins of old churches. Ottoman Georgians, like other Georgian Muslims, were claimed to have only superficially converted to Islam, a fact which was linked to their allegedly having been converted by force. ${ }^{28}$ Such a discourse of the "secret Christianity" and "superficial Islam" (both of which became widespread in subsequent Georgian national- 
ist discourses from the socialist period onward [see Pelkmans 2006, $108,120])$ allowed Georgians to have their cake and eat it too; they could engage in a secular public discourse in which they ignored religious differences and privately engage in the fantasy that their Muslim brothers really weren't very Muslim after all and were actually secretly Christians. ${ }^{29}$

Like the rest of the discourse of mutual "recognition at a glance," Georgian secular discourse was itself superficial. Georgians created a fantasy in which language and "nationality" (eroba) would create mutual recognition and reconciliation on purely secular grounds, and at the very same time, often in the same breath, imagined that the religious difference between themselves and the Ottomans was probably only skin deep, a surface glaze of Islam under which hid a secret Christian, a product of an imagined history of coercive conversion associated with Islam. As a result of the contradictions and antinomies of this putatively secular discourse of nationality which was inherited and crystallized under socialism and post-socialism, erstwhile Ottoman Georgians in regions like Ajaria remain afflicted with irresolvable dilemmas because they were "partly included and partly excluded from the Georgian national imagery. In this imagery, Ajarian Muslims were not complete 'others' but were rather 'incomplete selves'; they were simultaneously brother and potential enemy" (Pelkmans 2006, 140). Ironically, this "incomplete self," it might be argued, was produced by the sincere attempt to create a secular basis for national identity, in which both the concept of nationality and individual Ottoman Georgians alike were "emptied" of religious content. However, the difference that was repressed continuously returned: under socialism, for example, largely Christian Georgian cadres used official atheism primarily to physically repress Islamic difference even as socialist history of the region erased Islam as being a superficial symptom of a tragic history of violent, coercive, and backward Ottoman or Islamic rule, having no organic relation to national identity (Pelkmans 2006, 106-9). In the postsocialist period, with the resurgence of Orthodoxy as an integral part of Georgian nationalism, this secular socialist discourse treating Islam as a side effect of a tragic history of violence and coercion, thereby effectively erasing Islam, was retooled and integrated into an explicitly Christian narrative of the nation, producing further dilemmas for Ajarian Muslims (see Pelkmans 2006, 91-168). 
Even worse, Georgian secular discourse was careful to separate religious from secular identity only in careful speech on special occasions: while Georgians were careful to speak of "Georgians who have become Muslim" when emphasizing the opposition between secular and religious identity, in informal contexts these were simply Tatars, lumped together indifferently with all the other Muslims of the Russian Empire. In other words, Georgians spoke of the inhabitants of Ottoman Georgia not in terms of secular nationality or language, but in confessional terms of Ottoman millet. Their public secular discourse of national identity, adopted specifically to deal with the Ottoman case, was systematically belied by an informal private discourse privileging religious alterity.

Bavreli, for example, for most purposes uses the term "Tatar" in distinction to "Georgian"; he does not refer to Ottoman Georgians as "Georgians" (kartveli) in general but as Tatars (as opposed to Armenians and "French" [prangi, Georgian Catholics]). If Bavreli wishes to indicate that the Tatars in question are in some sense Georgians, he usually calls them "Tatars like us" or "our kind of Tatars" (chveneburi tatrebi). ${ }^{30}$ Usually, however, he uses the term Tatari to mean "Ottoman Georgian" and Kartveli to mean "Christian Georgian":

From the very first glance you can tell the local Armenians from the Tatars, although there is no difference in clothing. The Armenians are mobile, active, the Tatars gentle and slow in their movements, and along with that have peaceful faces. You already know about the clothing of Tatar women. Many of them wear Georgian style dresses; if a miracle happened and you were to see somewhere a Tatar woman in a Georgian dress, you wouldn't be able to tell whether she was a Georgian [kartveli] woman or a Tatar one. Especially among the Begs there are such, which represent a real Kartlian [kartlis] Aznauri. If you saw the deputy from Ardanuji, Emin-Afendi, well, how could you distinguish him from a Georgian [kartveli] ${ }^{31}$

Sometimes, he finds that the opposition between "Tatar" and "Georgian" is recursive and can reside within a single individual, perhaps as 
accident (clothing) to essence (features): "I asked a young Tatar, whose white chalma said, 'I am a Tatar,' but whose black eye brows, face beautiful to see, and large nose were to the contrary: 'No, I am a Georgian."'32

When Georgians spoke officially in the liberal secular mode about the Ottoman Georgians, they indicated their recognition of their common nationality as Georgians irrespective of religious difference by the careful use of phrases such as Gamahmadianebuli Kartvelebi "Georgians who have become Muslim," which carefully separates religious and secular (national) identity. However, as Ottoman Georgian complained (their voices dutifully transcribed by Georgian intelligentsia) such careful phrases separating religious from secular (national) identity (this Ottoman uses the phrase musulmani Gurji) is belied by the frequent colloquial use of terms like "Turk" and "Tatar" to describe them:

Although in terms of religion we are indeed nowadays Muslim Georgians (Musulmani Gurjebi), nevertheless in terms of descent we are Georgians (Kartvelni) and not Ottomans or Turks who have come in. . . . Everyone calls us 'Turk' and Georgians (Kartvelebi) loathe us most of all..$^{33}$

All pieties expressed at supras aside, Georgian commentators agree that this is the general stereotype, explaining that, among other things, it works the other way around too, that the term "Georgian" for Ottomans (Ajarians, in this case) includes all "Christians" regardless of ethnicity or type.

Previously some Armenian priest signing himself 'Meghushi' wrote 'the Ajarians hate Georgians.' First of all he should have understood this: Who are they [The Ajarians] calling 'Georgians' [Kartvelebs]? Georgian and Christian are synonyms. Georgia [Sakartvelo] and Christianity are for them one and the same thing. ${ }^{34}$

The failure of discourses of "nation" to disentangle themselves from "religion" was quite general all through these territories. Bavreli, like most commentators, essentially uses an Ottoman millet classificationclassification by confessional community-so that each community 
he describes contains Armenians and Tatars, and also Prangi (literally "French," Georgian Catholics). However, here too, attempts were made to recruit these "French" to the category of secularized Georgianness. In 1876, Sergi Mesxi issued an editorial in Droeba in response to a local correspondence from Axalcixe that a local Armenian priest was trying to convince the Georgian Catholics that they were Armenians and not Georgians, trying hard to spread the Armenian language among such Georgians "who in their own time were not Armenians and who also consider themselves to be real Georgians." ${ }^{35}$ Mesxi points here to the more general failure of this secular project:

The complete entanglement that exists among us between religion, people (xalxi), nation (nacia) is astonishing; we haven't been able to separate religion and nation from each other: If a Georgian, due to whatever circumstances, let us say, has accepted the Catholic religion, this person no longer considers themselves Georgian, but 'French' ('Prangi'), as if the change of religion changed their Georgianness (nationality). ${ }^{36}$

The most assiduous chronicler of the depopulation of Ottoman Georgia was Bavreli, who, at the end of his travels, in his imagined survey in an aerostat, asked finally whose fault was it that this much anticipated recognition did not happen. Having taken for granted that the matter would take care of itself, that recognition would happen at a glance, did the Georgians attempt to circulate themselves among the Ottoman Georgians? No. Bavreli anticipates Alxanishvili by a generation, chiding the Georgian intelligentsia for the failure on the ground of the very thing that the supra promised to have done at the ritual level and perform an act of recognition that would lead to reconciliation of "our long-lost brothers." He blames the Georgian intelligentsia, the Georgian aristocracy, the imposition of Russian imperial taxation, and (of course) Ottoman Georgian Muslim fanaticism:

Well how did the Georgians [Kartvelebi] make them [Ottoman Georgians] see, that they were brothers [modzmeebi] of the Ajarians? In this case too our youth were unable to fulfill their own duty: their "Ohs" and "Ahs" 
were for naught! . . last year I said, that we should make every effort that there be appointed in Ajaria and other places Georgians of good conscience; but our wish went for nothing; it is true, there were and are Georgians, but they are few and without effect, they too are under the influence of others and circumstances. . . . It didn't happen, we could not make them love us, for various reasons. ${ }^{37}$

In one of his very last published writings, Bavreli again takes his imaginary aerostat out of storage to give us one last look at Ottoman Georgia as a whole. By 1891, Ottoman Georgia has well and truly been forgotten by Georgian society; there is nothing written from the region and the region has few Georgian visitors:

Lo, it has now been ten or eleven years, that nothing has been written from Muslim Georgia in Georgian newspapers. ... In the passing of a tenth of a century what have we, Georgians, done in this newly-conquered region? The answer is very short: nothing, except this, that some Georgians, either for reasons of work or for scientific purposes, have visited the district of Artvin and reminded the local Mohamedanized Georgians that 'Your ancestors were Georgians' and nothing much more, and with that the matter ends. ${ }^{38}$

According to Bavreli, a "wall of fanaticism raised by historical circumstances stands between us and them." But more than anything else, behind the repetition of tired banalities about ancient kinship, we sense that Georgians are bored or tired of Ottoman Georgia. The relationship looks very similar from the Ottoman Georgian perspective, who patiently agree in turn "Baili [Yes], we are Gurjis," but one third of them have long since left for Ottoman lands, and the rest of them are looking for a means to do so.

The only Georgians who visit this land are here because their work takes them there (making them like the chinovnik who Bavreli travels with early on, for whom each post or place he travels is just another "somewhere" in the empire), and those who are there for scientific pur- 
poses (like Alxanishvili, writing just a few years later). The modality of scientific interest in Ottoman Georgia is not the Georgianness of the people (who, it is stipulated, are Georgians, but there is no ethnographic interest in reassembling the ruins of their Georgianness) but a specifically archaeological interest in the Georgian ruins of Ottoman Georgia. ${ }^{39}$ As we will see below, the monuments dotting the landscape provided a more durable set of outward signs of Georgianness, including language, in the form of Georgian inscriptions in ruined churches, than the people living among these ruins. The Georgianness of Ottoman Georgia belongs to the order of ruins and archaeological knowledge, the people are, and will remain strangers, hurrying off to a strange land. The moral of the story would be that the lands were Georgian, but not the people. To find living representatives of this secular semiotic model of Georgianness appropriate to ethnographic and folkloric description, Georgian writers in the 1880s would turn away from ruins of Georgianness in this region to the mountain dwellers on the northern borders of Georgia, "pagan" Georgians who were, if not Orthodox, at least were reassuringly not Muslims either (Manning 2006, 2007, 2008). 